\title{
The Quality Changes of Frozen and Dried Tiny Shrimp (Macrobrachium nipponense) Meat during Six Months Storage
}

\author{
Zarehgashti $\mathrm{Gh}^{* 1}$, Etemadian $\mathrm{Y}^{2}$, Khanipour $\mathrm{AA}^{1}$, and Fahim $\mathrm{A}^{1}$ \\ ${ }^{1}$ Inland Waters Aquaculture Research Center, Iranian Fisheries Science Research Institute, Agricultural Research \\ Education and Extension Organization (AREEO), Bandar Anzali, Iran \\ ${ }^{2}$ Young Researchers and Elite Club, Rasht Branch, Islamic Azad University, Rasht, Iran
}

${ }^{*}$ Corresponding author: Zarehgashti Gh, Inland Waters Aquaculture Research Center, Iranian Fisheries Science Research Institute, Agricultural Research Education and Extension Organization (AREEO), Bandar Anzali, Iran, E-mail: ghashtighorban@gmail.com

Citation: Zarehgashti Gh, Etemadian Y, Khanipour AA, Fahim A (2018) The Quality Changes of Frozen and Dried Tiny Shrimp (Macrobrachium nipponense) Meat during Six Months Storage. J Nutr Health Sci 5(2): 206. doi: 10.15744/2393-9060.5.206

Received Date: April 22, 2018 Accepted Date: May 24, 2018 Published Date: May 29, 2018

\begin{abstract}
In this study, Macrobrachium nipponense tiny shrimp meats using two methods of drying and freezing along with metalized polyethylene pouches were kept for 6 months. Then their chemical properties (proximate composition, thiobarbituric acid (TBARS), peroxide value (PV), total volatile nitrogen (TVB-N) and free fatty acids (FFA)), microbial (total bacteria count) and sensory (odor, flavor, and color) analyses were evaluated. The results showed that both methods are practical and appropriate. Because there was no negative effect on quality properties of dried and frozen shrimp meats. Also, there was no negative influence of the drying and freezing processes on the fatty acid composition of shrimp meats. The values of TBARS, PV, TVB-N, FFA and the counting of colonies increased with increasing time. But their values in all treatments were within acceptable limits. All samples have gained a good grade by trained panel members. In general, this study suggests the use of tiny shrimp (M. nipponense) for use in food industry.
\end{abstract}

Keywords: Tiny shrimp; Drying; Freezing; Storage; Shelf life

\section{Introduction}

The use of low-consumption fisheries resources such as small-sized fish and shrimp in third world countries have not been much developed so that these potential sources of food are only used to produce inhuman foods such as fish powders. Hence, due to population growth and willingness to ready-to-eat foods, the use of these resources can be lead to diversification in the production of aquaculture products and the development of conversion industries [1].

Macrobrachium nipponens is one of the economic species of Macrobrachium genus, first identified in 1849 by an American researcher named De Haan [2]. This shrimp is similar to two species of shrimp introduced into the Caspian Sea, Palaemon elegans and Palaemon adspersus, belonging to one family, and they are completely similar in appearance, with the exception that the second arm or leg of their fork is much longer than the Caspian Sea shrimp [3]. The main habitat of this shrimp is the eastern Asian rivers such as China, Japan, Korea, Malaysia, Myanmar, Taiwan and Vietnam [4-6]. M. nipponens tiny shrimp have been increasing in Anzali international lagoon in a few recent years. They also have high compatibility. The proper exploitation of them can prevent their excessive increase and also adjust their bio-cycle. Therefore $M$. nipponense has a good growth and economic value because of the adaptation to weather conditions and habitat type in every lagoon [5,6]. Therefore their reserves are increasing, but so far no action has been taken to apply them in food products for the human consumption.

In general, all marine foods such as fish and shrimp apply to strengthen the body's defense systems. It also helps in boosting body resistance, improving inflammation, heart disease and cancer control [7]. With essential amino acids, unsaturated fatty acids, vitamins, and minerals, these shrimp can play an important role in the human food chain [8]. Drying and freezing techniques are conventional conservational methods of food preservation. The basis of these techniques is preventing the protein deterioration, reduction of microbial growth and shelf-life increase of the final products [9]. Because aquatic animals have about $75-85 \%$ water in the body, they rapidly destroy by microorganisms at the temperature of $5{ }^{\circ} \mathrm{C}$ or more than $5{ }^{\circ} \mathrm{C}[10]$. Hence, the purpose of this project was to determine the nutritional value and quality changes of frozen and dried M. nipponens tiny shrimp during 6 months and then its introduction to the food industry. Also, their annual exploitation from Bandar-Anzali lagoon can somehow prevent 
from threatening them for lagoon native organisms in the future.

\section{Materials and Methods}

\section{Shrimp collection and preparation}

About $20 \mathrm{~kg}$ of $M$. nipponense shrimp was caught from the Siah Darvishan region of Anzali lagoon from 25 June to 20 August 2016. This place is situated in Gilan, Caspian Sea, Iran; its geographical coordinates are $37^{\circ} 22^{\prime} 56^{\prime \prime}$ North, 49 $25^{\prime} 20^{\prime \prime}$ East. All samples were brought to the laboratory of National Aquaculture Processing Center (UNIDO), Bandar Anzali (Gilan, Iran). The samples were washed with the cold water $\left(3^{\circ} \mathrm{C}\right)$ to separate dirt, sand and other potential contaminants. The shrimp were then divided into two groups. The first group was packed in rectangular packages and frozen by the freezing tunnel and the second group was dipped in $\mathrm{NaCl}$ solution $(10 \% \mathrm{~W} / \mathrm{V}$ ) with a ratio of 1 to 2 (shrimp: $\mathrm{NaCl}$ solution) at boiling temperature for 3 min. After spreading them on leaky trays, the excess water was removed. They cooled for 10 minutes, then dried at $70{ }^{\circ} \mathrm{C}$ by cabinet-type air dryer (6 hours). The moisture content was lower than $10 \%$. The dried samples after removal of shell, head, and tail were under vacuum packaged in metalize films at ambient temperature. In the end, all samples (frozen and dried) were stored for 6 months at $-18{ }^{\circ} \mathrm{C}$ and ambient temperatures, respectively. Samples were sampled at 1, 3 and 6 months intervals with three replications.

\section{Measurement of proximate compositions}

Determination of protein content: The total protein content of the samples calculated on the basis of the nitrogen content, which was determined by the micro-Kjeldahl (Techno Service Co, Behr K 24, Germany) method system (N×6.25) [11].

Determination of crude lipid content: Crude lipid was extracted from the shrimp in a Soxhlet extractor (Behr, Labor-Technik, Germany) using petroleum ether. The crude lipid content was determined gravimetrically following oven-drying of the extract at $105^{\circ} \mathrm{C}$ overnight $[11]$.

Determination of ash content: The ash contents were estimated by heating the samples overnight in a furnace at $525^{\circ} \mathrm{C}$ for $16 \mathrm{~h}$ and weighed [11].

Determination of moisture content: The residual moisture content of the samples was determined by drying to a constant weight at $105^{\circ} \mathrm{C}$ in an oven [11].

Determination of salt content: $5 \mathrm{~g}$ of dried shrimp was weighted in a crucible and reduced to ashes in a furnace (Muffle Furnace, SEF-202, Korea) at $550{ }^{\circ} \mathrm{C}$ until constant mass was obtained. The ash was then cooled and transferred to a volumetric flask. That was washed with distilled water and the volume was adjusted to $100 \mathrm{ml}$ and then filtered by Whatman No. 1 filter paper. $20 \mathrm{ml}$ of it along with a few drops of $10 \%$ potassium chromate as an indicator was titrated with $0.1 \mathrm{~N}$ silver nitrate. The endpoint of titration was red brick color. The salt content (\%) was calculated as follows [12-14]:

$$
\text { Salt }_{\text {Value }}=\frac{\mathrm{ml} \text { silver nitrate } \times 0.005845 \times 100}{\text { Sample mass }(\mathrm{g})}
$$

Determination of fatty acid compositions: Fatty acid compositions of samples were assessed according to the protocol of Castro et al. [15]. Briefly, $0.075 \mathrm{~g}$ of samples were dissolved in $1 \mathrm{ml}$ of toluene and $2 \mathrm{ml}$ of $1 \% \mathrm{H}_{2} \mathrm{SO}_{4}$ (in methanol). The esters were extracted twice with $5 \mathrm{ml}$ of hexane. The organic layer was separated and washed with $4 \mathrm{ml}$ of $2 \%$ KHCO3. The mixture was dried using anhydrous $\mathrm{Na}_{2} \mathrm{SO}_{4}$ and filtered. The organic solvent was removed and fatty acid methyl ester (FAME) was subjected to gas chromatography [6890 N system, GC Agilent Technologies]. The initial temperature was $70{ }^{\circ} \mathrm{C}$, and then the temperature increased to $250^{\circ} \mathrm{C}$. The injection temperature was $220^{\circ} \mathrm{C}$. Helium was applied as the carrier gas at the flow rate of $1 \mu \mathrm{l} / \mathrm{min}$.

\section{Measurement of qualitative and microbial indicators during 6 months storage}

Determination of thiobarbituric acid (TBARS): Thiobarbituric acid substances (TBARS) were determined by the steam distillation method [16]. Briefly, $10 \mathrm{~g}$ of soup powder was transferred to a round bottom flask with $97.5 \mathrm{ml}$ of distilled water and was blended by hand for 2 minutes. While blending, $2.5 \mathrm{ml} \mathrm{HCl}(4 \mathrm{~N})$ was added to the mixture. Then, a few anti-bumping granules and antifoam were added. Samples were heated until 50 milliliters of distilled solution was obtained. TBA of soup powder was expressed as mg malondialdehyde/ kg sample and calculated by using the following formula:

$$
\mathrm{TBA}_{\text {Value }}=7.8 \times \mathrm{Abs}_{538}
$$

Determination of peroxide value (PV): The peroxide value (PV) was determined by AOAC and expressed as milli-equivalents of oxygen per $1000 \mathrm{~g}$ oil. Accurately $50 \mathrm{~g}$ soup powder was weighed into $250 \mathrm{ml}$ ground glass. $100 \mathrm{ml}$ chloroform was added [11]. 
The specimens were kept in a dark place for 2 hours and then filtered. $25 \mathrm{ml}$ of the filtered solution was transferred into a glass jar and placed under the hood to evaporate the solvent. To the rest of the filtered solution, $37 \mathrm{ml}$ acetic acid, $30 \mathrm{ml}$ distilled water, 1 $\mathrm{ml}$ potassium iodide and approximately $1 \mathrm{ml}$ starch solution were added. The solution was gently swirled. When it was completely evaporated, the amount of residual fat in the container was weighed. The residual solution was titrated with $0.01 \mathrm{~N} \mathrm{Na}_{2} \mathrm{~S}_{2} \mathrm{O}_{3}$. The PV of samples was calculated by using the following Formula: (V2: ml of sodium thiosulfate for titration, N: Normality of sodium thiosulfate, W: weight of lipid in grams).

$$
\mathrm{PV}_{\text {value }} \frac{\mathrm{V}_{2} \times \mathrm{N} \times 1000}{\mathrm{~W}}
$$

Determination of total volatile nitrogen (TVN): Total volatile nitrogen of the samples was determined according to the protocol of Woyewoda et al. [17]. Briefly, $10 \mathrm{~g}$ sample and $300 \mathrm{ml}$ distilled water was added to a round bottom distillation flask (1000 ml). After shaking the balloons by hand, 2 g magnesium oxide and anti-bumping granules were added. $25 \mathrm{ml}$ of $2 \%$ boric acid and a few drops of indicator (dissolve $1 \mathrm{~g}$ phenolphthalein in $100 \mathrm{ml}$ ethanol 95\%) was added to $250 \mathrm{ml}$ Erlenmeyer receiving flask. The distilling flask was heated so that liquid was boiled in exactly $10 \mathrm{~min}$. Using the same rate of heating was distilled for $25 \mathrm{~min}$. After distillation, the solution was titrated in the receiver flask back to the original color, using standard $0.1 \mathrm{~N} \mathrm{H}_{2} \mathrm{SO}_{4}$ solutions. Total volatile bases of samples expressed as mg nitrogen per $100 \mathrm{~g}$ sample:

$$
\mathrm{TVN}_{\text {value }}=\frac{\mathrm{mL} \text { sulfuric acid } \times \mathrm{N} \times 100 \times 14}{\text { Sample }(\mathrm{g})}
$$

Determination of free fatty acid (FFA): $10 \mathrm{~g}$ sample, $50 \mathrm{ml}$ chloroform and $50 \mathrm{ml}$ methanol was added to small blender jar. It was blended 1 minute until finely divided. Then it was filtered on a Buchner funnel through Whatman No. 4 filter paper and rinsed with a small amount of chloroform. $45 \mathrm{ml}$ distilled water was added to the filtrate to achieve a final chloroform/methanol/ water ratio of 1:1:1, swirled gently, and transferred to $250 \mathrm{ml}$ separatory funnel. The flask was rinsed with chloroform, added washings to a separatory funnel and left 2 or 3 hours (or preferably overnight) at room temperature. After equilibrium, the lower chloroform layer from the separatory funnel using a regular funnel was slowly filtered through a double $15 \mathrm{~cm}$ filter paper (Whatman No. 4 inside and Whatman No. 1 outside) half was filled with anhydrous sodium sulfate into a $100 \mathrm{ml}$ volumetric flask. It was rinsed with chloroform but was not exceed mark of volumetric. Then it was filled to mark with chloroform. Three $10 \mathrm{ml}$ aliquots of chloroform filtrate were transferred into pre-weighed aluminum dishes and allowed to evaporate the solvent. When it was completely evaporated, the dish was placed in an oven at $103{ }^{\circ} \mathrm{C}$ for one hour. Then after cooling, it was weighted. The remaining volumetric solution was transferred to $250 \mathrm{ml}$ Erlenmeyer flask. It was rinsed with $10 \mathrm{ml}$ chloroform. Then, $70 \mathrm{ml}$ 2-propanol, $35 \mathrm{ml}$ methanol and 8 drops meta-cresol purple indicator were added to it. It was titrated to the violet endpoint with $0.05 \mathrm{~N} \mathrm{NaOH}$. A blank containing all reagents except the sample was titrated. The free fatty acid content was expressed as percent oleic acid $[14,17]$.

\section{Determination of color}

The color parameters $L^{\star}$ (lightness), $\mathrm{a}^{\star}$ (redness), $\mathrm{b}^{\star}$ (yellowness) of samples were measured by using a colorimeter (NR60CP Precision Colorimeter, 3nh, China).

\section{Sensory evolution}

Sensory evaluation of the samples was performed by 7 panelists based on the 5-point system [18]. At the beginning of the test, they were asked to rinse their mouth with water and then smell and taste the prototypes. Finally, sensory scores were calculated from 0 to 5 for each sample in order to assign a value for the statistical analysis $(0=$ very bad, $1=$ bad, $2=$ medium, $3=$ good, $4=$ very good, $5=$ excellent).

\section{Total bacteria enumeration}

Pour plate method was used in order to enumerate total bacteria. This means that the suspension of peptone water (45 ml) with the sample ( $5 \mathrm{~g}$ ) was prepared at various dilutions. Then, $1 \mathrm{ml}$ of them moved into the sterile plates. Appropriate culture medium with bacteria (Plate Count Agar) and mold and yeast (Yeast Glucose Chloramphenicol Agar) were pre-sterilized. When their temperature reached $45^{\circ} \mathrm{C}$, about $15-20 \mathrm{ml}$ was added to the plate. The plate was thoroughly mixed by the rotational movement. The plates were incubated at $37^{\circ} \mathrm{C}$ for 2 days (bacteria) and $23^{\circ} \mathrm{C}$ for 5 days (mildew and yeast) [19]. Counting of colonies was calculated by the following formula:

$$
\mathrm{N}_{\text {value }}=\frac{\Sigma c}{V\left(\mathrm{n} 1+0.1 \mathrm{n}_{2}\right) d}
$$


$\mathrm{N}$ : number of microorganisms; c: the total number of colonies counted in all plates selected from two consecutive ranges; V: inoculated volume per plate $(\mathrm{ml}) ; \mathrm{n} 1$ : number of plates counted at the first dilution selected; $\mathrm{n} 2$ : number of plates counted at the second dilution selected; $d$ : the dilution coefficient was selected based on the first dilution.

\section{Statistical analysis}

The statistical analysis was performed using the SAS software. Duncan's Multiple Range test ( $\mathrm{p}=0.05$ ) was used to determine any significance of differences between specific means (The SAS System for Windows 9.0, English). All determinations were performed in triplicate, and the data were expressed in terms of mean \pm standard deviation (SD).

\section{Results}

The proximate compositions of frozen and dried shrimp meats are shown in Table 1. The results indicated that frozen samples had the high moisture (78.18 \pm 0.32$)$, intermediate protein (17.25 \pm 0.35$)$, and low lipid $(1.84 \pm 0.36)$ contents. After drying, the protein, fat and ash contents were increased to $73.74 \pm 1.99$ and $3.03 \pm 0.75$, respectively. The moisture content decreased to $6.32 \pm 0.07$. The amount of salt was only measured in dry samples due to the amount of salt added during treatment. The results showed that samples had a suitable salinity and less than $5 \%$ of dry weight.

\begin{tabular}{|c|c|c|c|c|c|}
\hline \multirow{2}{*}{ Samples } & \multicolumn{5}{|c|}{ g/100g dry weight } \\
\cline { 2 - 6 } & Moisture & Protein & Fat & Ash & Salt \\
\hline Frozen & ${ }^{*} 78.18 \pm 0.32$ & $17.25 \pm 0.35$ & $1.84 \pm 0.36$ & $1.99 \pm 0.01$ & - \\
\hline Dried & $6.32 \pm 0.07$ & $73.74 \pm 1.99$ & $3.03 \pm 0.75$ & $7.33 \pm 0.01$ & $3.49 \pm 0.07$ \\
\hline
\end{tabular}

The fatty acid composition of frozen and dried shrimp meats is shown in Table 2. The relative content of C16:0 was significantly higher in dried shrimp meat than in frozen ones $(P<0.05)$, with contents of $18.49 \pm 0.14 \%$ and $15.18 \pm 0.04 \%$, respectively. However, other contents of SFA had no significant difference $(P>0.05)$. The sum of SFA was $30.08 \%$ in frozen shrimp meat and $33.36 \%$ in cabinet-type air-dried samples. The total content of MUFA was $17.01 \%$ in frozen shrimp meat and $21.0 \%$ in dried samples. The amounts of PUFA varied from about $34.89 \%$ in frozen samples to $38.92 \%$ in dried ones. Linoleic acid (C18:2) was the most abundant PUFA and its concentration was $15.65 \pm 0.19 \%$ and $19.67 \pm 0.01 \%$ in the frozen and dried samples, respectively. The content of linoleic acid increased significantly after drying processes $(P<0.05)$. Other contents of PUFA did not show a significant difference between the frozen and dried samples $(P>0.05)$. EPA (C20:5) and DHA $(\mathrm{C} 22: 6)$ are the most important unsaturated fatty acids of shrimp. The dried samples showed the highest level of EPA $(9.69 \pm 0.01 \%)$ and DHA $(8.51 \pm 0.01 \%)$, but there was no significant difference between the frozen and dried shrimp meat $(P>0.05)$.

\begin{tabular}{|c|c|c|c|c|}
\hline \multirow{2}{*}{\multicolumn{3}{|c|}{ Fatty acid composition (\%) }} & \multicolumn{2}{|c|}{ Condition } \\
\hline & & & \multirow{2}{*}{$\frac{\text { Dried }}{0.31^{\mathrm{b}} \pm 0.01}$} & \multirow{2}{*}{$\begin{array}{c}\text { Frozen } \\
0.32^{\mathrm{b}} \pm 0.03\end{array}$} \\
\hline \multirow{5}{*}{ SFA } & Meristic acid & C14:0 & & \\
\hline & Palmitic acid & C16:0 & $18.49^{\mathrm{a}} \pm 0.14$ & $15.18^{\mathrm{b}} \pm 0.04$ \\
\hline & Stearic acid & C18:0 & $13.02^{\mathrm{c}} \pm 0.01$ & $13.04^{c} \pm 0.08$ \\
\hline & Arachidic acid & C20:0 & $0.41^{\mathrm{b}} \pm 0.01$ & $0.42^{\mathrm{b}} \pm 0.03$ \\
\hline & Behenic acid & C22:0 & $1.13^{\mathrm{b}} \pm 0.01$ & $1.12^{\mathrm{b}} \pm 0.10$ \\
\hline \multirow{3}{*}{ MUFA } & Palmitoleic acid & C16:1 & $1.13^{\mathrm{b}} \pm 0.01$ & $1.13^{\mathrm{b}} \pm 0.03$ \\
\hline & Oleic acid & C18:1 & $19.28^{\mathrm{a}} \pm 0.01$ & $15.32^{\mathrm{b}} \pm 0.01$ \\
\hline & Gadoleic acid & C20:1 & $0.59^{\mathrm{b}} \pm 0.01$ & $0.56^{\mathrm{b}} \pm 0.02$ \\
\hline \multirow{4}{*}{ PUFA } & Linoleic acid & C18:2 & $19.67^{\mathrm{a}} \pm 0.01$ & $15.65^{\mathrm{b}} \pm 0.19$ \\
\hline & Linolenic acid & C18:3 & $1.05^{\mathrm{c}} \pm 0.01$ & $1.08^{\mathrm{c}} \pm 0.07$ \\
\hline & Eicosapentaenoic acid & C20:5 & $9.69^{c} \pm 0.01$ & $9.68^{c} \pm 0.26$ \\
\hline & Docosahexaenoic acid & C22:6 & $8.51^{\mathrm{c}} \pm 0.01$ & $8.48^{\mathrm{c}} \pm 0.32$ \\
\hline
\end{tabular}

Values in the same row followed by a different letter are significantly different $(P<0.05)$

Table 2: Fatty acid compositions of frozen and dried shrimps

The results of TBARS index in frozen and dried shrimp meat during 6 months of storage, respectively in $-20{ }^{\circ} \mathrm{C}$ and ambient temperatures (Figure 1) showed that with the increase in storage time, the amount of TBARS was increased. Therefore, the effect of time was significant $(\mathrm{P}<0.05)$. Figure 2 shows the amount of peroxide $(\mathrm{PV})$ in frozen and dried shrimp meat during six months storage, respectively in freezer and ambient temperatures. The results indicated that PV such as TBARS increased with the increase in storage time $(\mathrm{p}<0.05)$. Figure 3 shows the variation of TVN between frozen and dried samples during six months of storage in $-20{ }^{\circ} \mathrm{C}$ and ambient temperatures, respectively. The results showed that the amount of TVN in different treatments increased with the increase in storage time $(\mathrm{p}<0.05)$. This increase was statistically significant $(\mathrm{p}<0.05)$. However, there was no significant difference separately between samples in the first and third months $(p>0.05)$. 


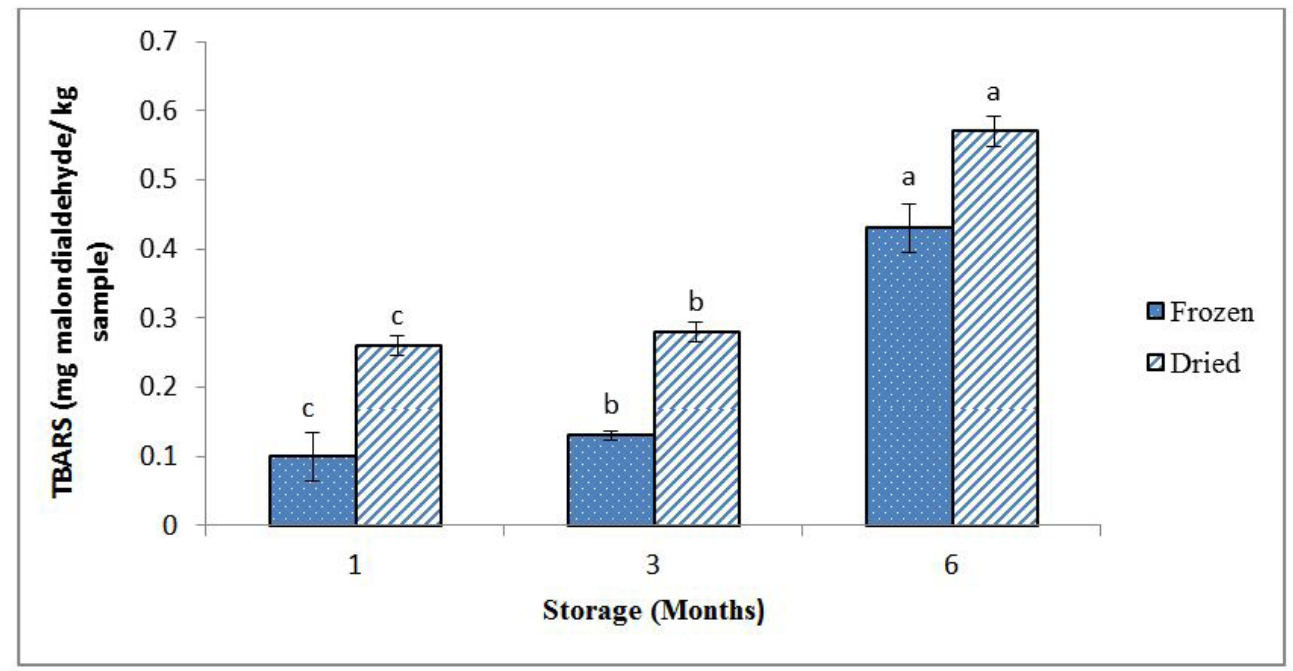

Figure 1: TBA values of the frozen and dried shrimp meat during six months of storage

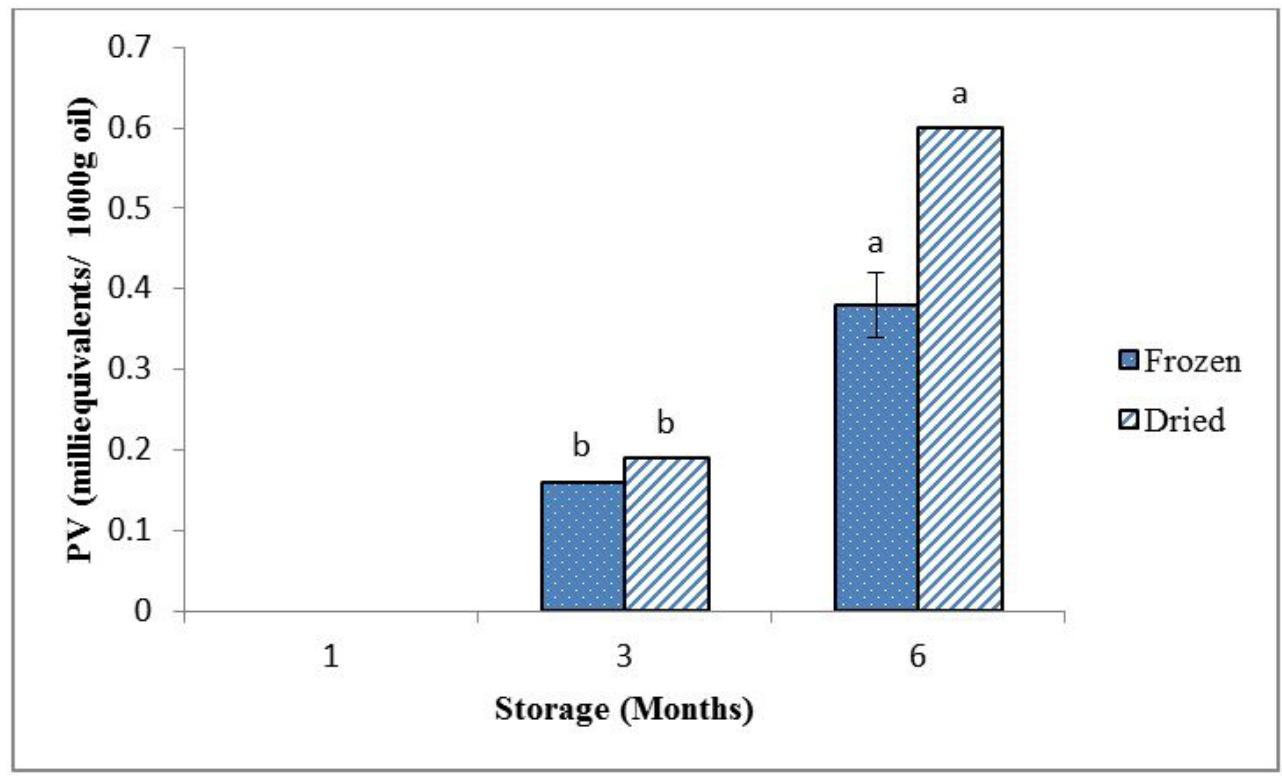

Figure 2: $\mathrm{PV}$ values of the frozen and dried shrimp meat during six months of storage

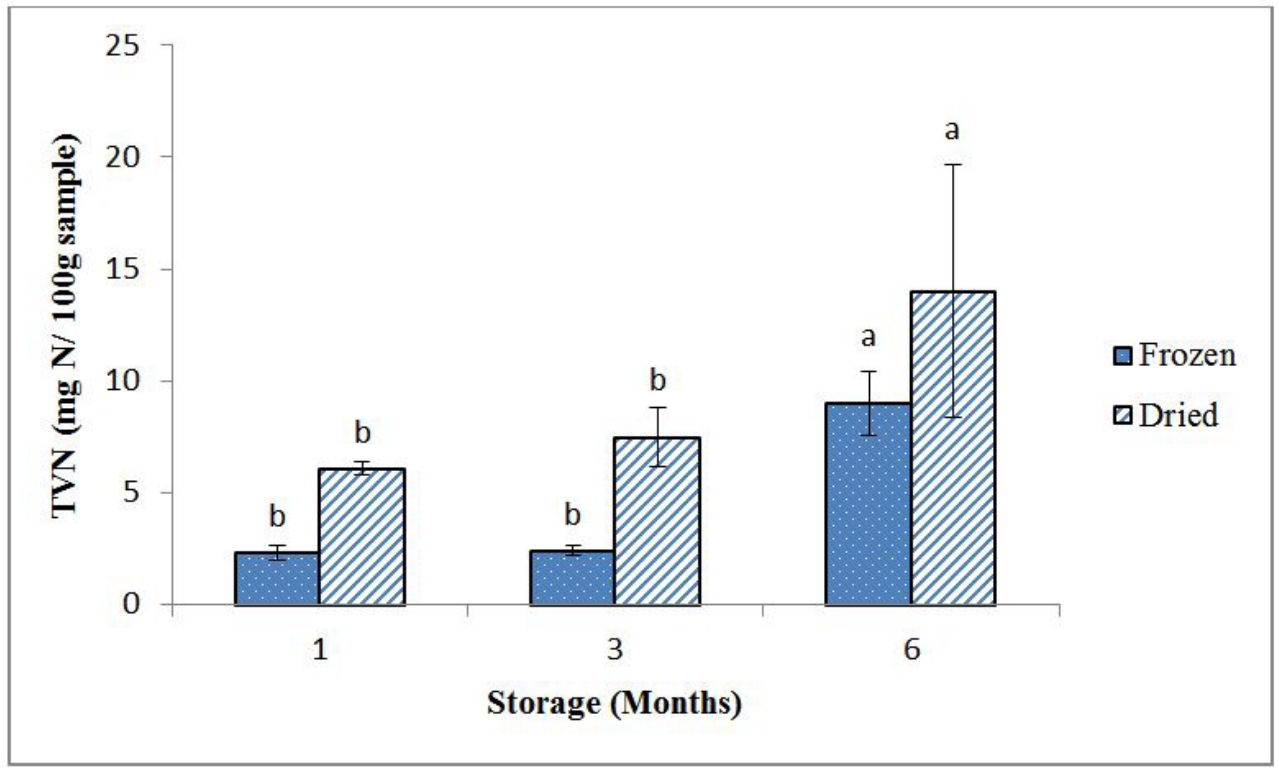

Figure 3: TVN values of the frozen and dried shrimp meat during six months of storage 
The results of measuring FFA in terms of oleic acid content are given in Figure 4. The results showed that the amount of FFA was respectively low and high in frozen and dried samples during six months of storage. However, the storage time did not effect on both samples $(p>0.05)$.

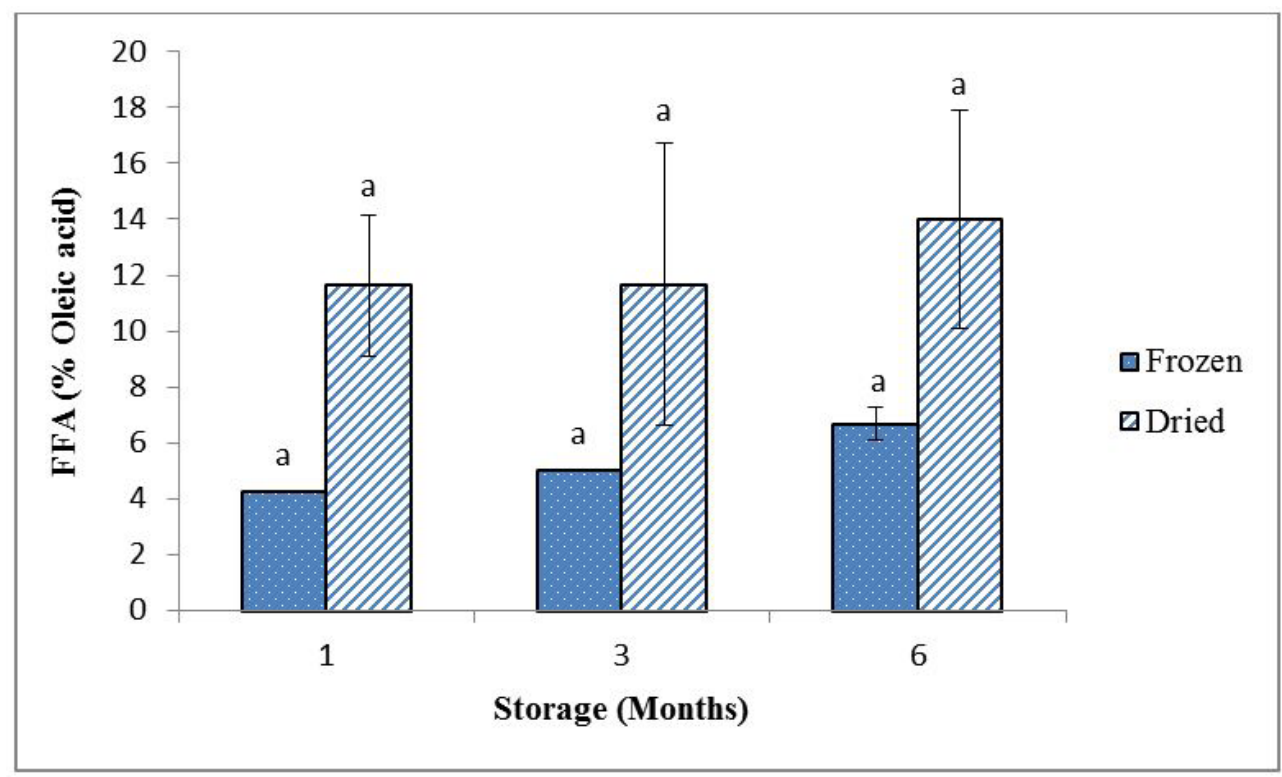

Figure 4: FFA values of the frozen and dried shrimp meat during six months of storage

Table 3 shows the results of measuring the color in frozen and dried shrimp meats. As the storage time increased, there was no significant difference in the amount of lightness $\left(\mathrm{L}^{\star}\right)$ of dried samples and frozen samples. Also, in terms of redness and yellowness $\left(a^{\star}\right.$ and $\left.b^{*}\right)$, the dried shrimp by the cabinet-type air dryer, showed higher values.

\begin{tabular}{|c|c|c|c|c|}
\hline \multirow{2}{*}{ Samples } & \multicolumn{4}{|c|}{ Storage (Months) } \\
\cline { 2 - 5 } & Parameters & $\mathbf{1}$ & $\mathbf{3}$ & $\mathbf{6}$ \\
\hline \multirow{3}{*}{ Frozen } & $\mathbf{L}^{*}$ & $49.83^{\mathrm{a}} \pm 3.63$ & $45.70^{\mathrm{a}} \pm 0.45$ & $41.89^{\mathrm{a}} \pm 1.93$ \\
\cline { 2 - 5 } & $\mathbf{a}^{*}$ & $-1.47^{\mathrm{a}} \pm 0.58$ & $-1.45^{\mathrm{a}} \pm 0.46$ & $-0.60^{\mathrm{a}} \pm 0.71$ \\
\cline { 2 - 5 } & $\mathbf{b}^{*}$ & $-3.37^{\mathrm{a}} \pm 1.21$ & $-2.70^{\mathrm{a}} \pm 0.90$ & $-1.49^{\mathrm{b}} \pm 0.13$ \\
\hline \multirow{3}{*}{ Dried } & $\mathbf{L}^{*}$ & $70.56^{\mathrm{a}} \pm 1.27$ & $74.28^{\mathrm{a}} \pm 1.00$ & $76.19^{\mathrm{a}} \pm 0.54$ \\
\cline { 2 - 5 } & $\mathbf{a}^{*}$ & $15.75^{\mathrm{a}} \pm 0.23$ & $14.50^{\mathrm{b}} \pm 0.18$ & $13.40^{\mathrm{c}} \pm 0.33$ \\
\cline { 2 - 5 } & $\mathbf{b}^{*}$ & $29.04^{\mathrm{a}} \pm 0.57$ & $26.69^{\mathrm{b}} \pm 0.12$ & $24.69^{\mathrm{c}} \pm 0.12$ \\
\hline
\end{tabular}

Values in the same row followed by a different letter are significantly different $(P<0.05)$.

Table 3: Color parameters of frozen $\left(\right.$ at $-18^{\circ} \mathrm{C}$ ) and cabinet-type air dried shrimp meats

Figure 5 shows the results of the sensory evaluation (color, odor, flavor/taste and texture) of frozen and dried shrimp meats. The frozen and dried shrimp meats have gained an acceptable score by trained panel members during six months of storage.

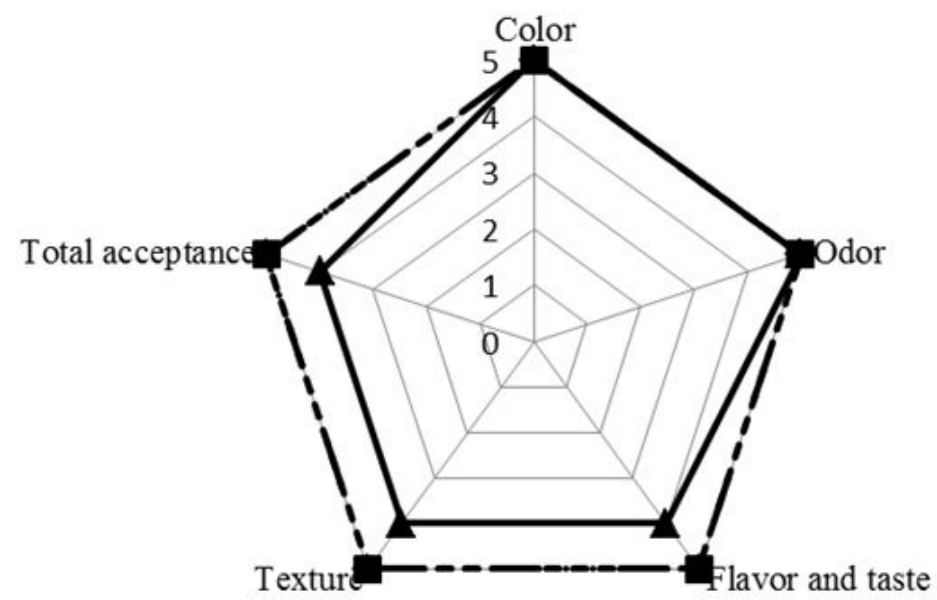

\section{Frozen}




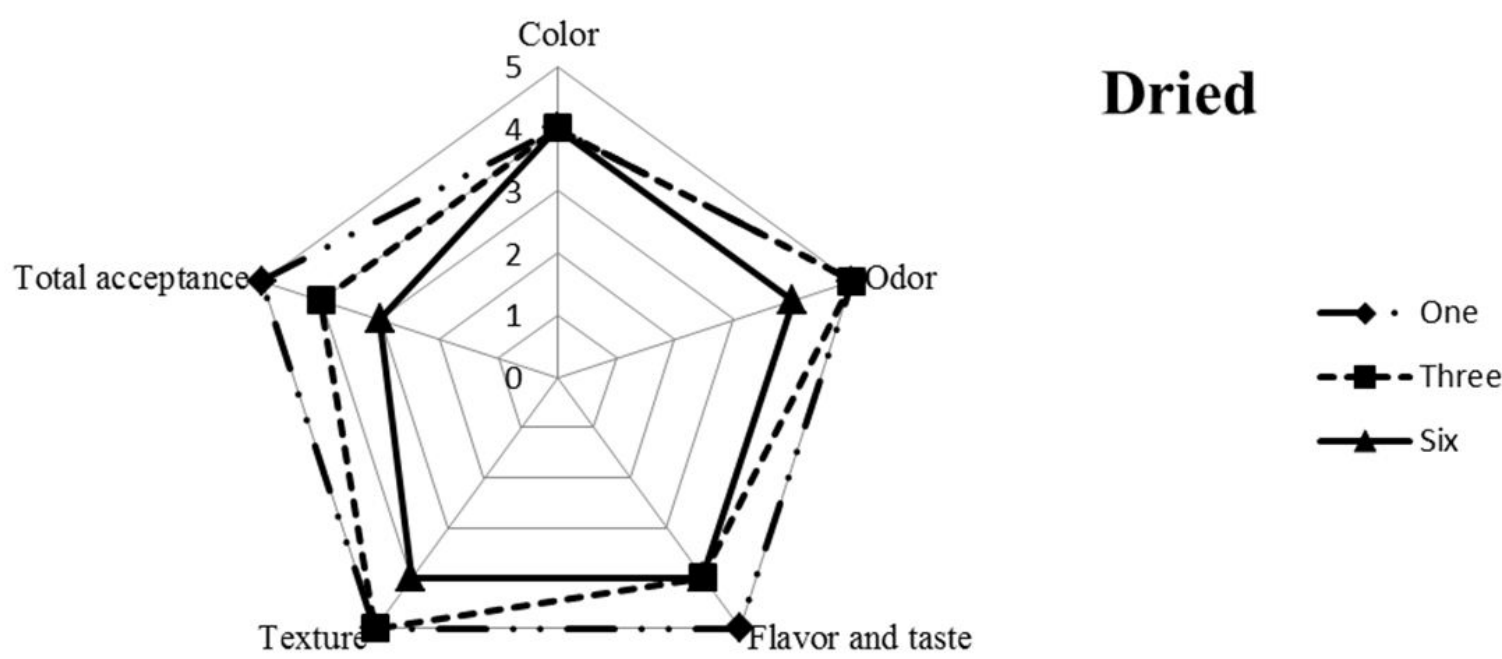

Figure 5: Sensory analyses of the frozen and dried shrimp meat during six months of storage

The results of counting the total bacteria (Table 4) showed that with increasing storage time, the number of microorganisms increased especially in dried samples. But this increase was in a satisfactory range. The dried shrimp meat by cabinet-type air dryer compared to frozen shrimp meat showed more the number of microorganisms which was statistically significant $(p<0.05)$. Regarding the count of mold and yeast, there was no significant difference in both samples.

\begin{tabular}{|c|c|c|c|c|}
\hline \multirow{2}{*}{$\begin{array}{l}\text { Microorganism count } \\
\quad(\mathrm{cfu} / \mathrm{g} \text { sample })\end{array}$} & \multirow{2}{*}{ Condition } & \multicolumn{3}{|c|}{ Storage time (month) } \\
\hline & & 1 & 3 & 6 \\
\hline \multirow{2}{*}{ Total bacteria } & Frozen & $1 \times 101^{\mathrm{a}}$ & $1 \times 101^{\mathrm{a}}$ & $3 \times 101^{\mathrm{a}}$ \\
\hline & Dried & $2 \times 101^{a}$ & $6.3 \times 101^{\mathrm{a}}$ & $1.5 \times 102^{b}$ \\
\hline \multirow{2}{*}{ Mold and yeast } & Frozen & $1 \times 101^{\mathrm{a}}$ & $1 \times 101^{\mathrm{a}}$ & $1 \times 101^{\mathrm{a}}$ \\
\hline & Dried & $1 \times 101^{a}$ & $1 \times 101^{\mathrm{a}}$ & $1.1 \times 101^{\mathrm{a}}$ \\
\hline
\end{tabular}

\section{Discussion}

The high moisture, intermediate protein, and low lipid contents in frozen samples, similar to previous reports [20, 21]. The decrease of moisture content was the most prominent change in shrimp meats after drying with a cabinet-type air dryer. Concomitantly, the drying was caused significant changes in protein, fat and ash compounds of shrimp meat. The significant increase in protein contents of dried shrimp meat was in accordance with the findings of other researchers [20-22]. After drying, there was also a significant increase in fat and ash contents compared with freezing method. These results showed that the increase in fat and ash of dry samples has a direct correlation with the decrease in moisture. On the other hand, the drying process affected the amount of salt absorption. For example, Niamnuy et al. with a study on quality changes of shrimp during boiling in salt solution reported that the salt absorption content in the shrimp meat increased with increasing the boiling time ( $\mathrm{min}$ ) [13]. In their study, 3 minutes of boiling resulted in 5\% salt absorption. But in this study, the salt content with 3 minutes of boiling resulted in $3.49 \pm 0.07 \%$.

In frozen and dried shrimp meats, palmitic acid (C16:0) was the most abundant saturated fatty acid (SFA). On the other hand, oleic acid (C18:1) and linoleic acid (C18:2) were the predominant fatty acid in the class of MUFA and PUFA. PUFA is fundamental for forming elements of cell membranes, important structural lipids, and precursors of eicosanoids, which influence inflammation processes and immune reactions [20,23,24]. Therefore, it is beneficial for the human health. Overall, the results of this study showed that the relative quality of both methods for this tiny shrimp fatty acids were acceptable.

The TBARS index is usually measured in order to evaluate the lipid oxidation rate and shows the secondary production of oxidation, especially aldehydes [25]. The presence of such compounds causes changes in the sensory characteristics, including flavor and odor in frozen and dried products. The National Iranian Standards Organization has identified the maximum 2 mg malondialdehyde/ kg sample as an acceptable limit in frozen and dried products [19]. Also, Greene and Cumuze reported that the values of TBARS above $0.6 \mathrm{mg}$ malondialdehyde/ $\mathrm{kg}$ sample of these products can be detected in the sensory evaluation by trained people [26]. The results of this study also showed that with the increase in storage time, the amount of TBARS was increased, but the value in all treatments was in acceptable limits during 6 months. The minimum content of TBA in frozen samples can be due to the use of a good condition of freezing (no fluctuations in temperature) and packaging (use of polyethylene packs). On the other hand, the low content of TBARS in dried samples can be due to use of the salt during the drying process and suitable 
packaging especially the use of metalized films. However, there was a difference between dried and frozen shrimp meats. The quality changes in frozen samples were lower than dried samples. In general, all treatments were in a suitable condition in terms of the lipid oxidation until the sixth month. In another study by Kraemer on the malonaldehyde concentration in salted-dried shrimp reported that the values of TBARS were between 0 and1.24 mg malondialdehyde/ $\mathrm{kg}$ sample [27]. Also, Sampaio et al. studies on the cholesterol oxidation in salted-dried shrimp showed that the values of TBARS were vary from 0.02 up to $1.30 \mathrm{mg}$ malondialdehyde/ kg sample [28].

The peroxide value indicates the total amount of hydro-peroxides and is one of the primary and important indicators of lipid degradation measurements [29]. However, in the first month no peroxide value was recorded in both samples. In the third and sixth months, the content of PV in samples was lower than 1 milli-equivalent peroxide per kilogram of lipid. It can be concluded that the third month is the start month of quality changes in the peroxide value of frozen and dried shrimp meat. Wu and Mao studies on dried grass carp (Ctenopharyngodon idellus) fillets found that peroxide value was a poor indicator in heated samples [20]. Also, they reported that use of high temperature for drying process could accelerate the breakdown of peroxides into carbonyl compounds, and thus the peroxide value may remain low. But their results were different from dried shrimp results in this study, because in this project the temperature at all stages was not higher than $70{ }^{\circ} \mathrm{C}$ for drying samples.

TVN is an indicator for the novelty detection in food products [30]. They include a wide range of volatile compounds, such as ammonia, methylamine, dimethylamine, trimethylamine and other similar compounds [31]. They are produced by the activity of enzymes, proteolytic bacteria and protein degradation [32]. The factors that create TVN in aquatic meat are enzymes present in meat and microorganism activity [10]. Therefore, its increase during the maintenance period can be attributed to the activity of bacteria causing corruption. Because high activity of bacteria breaks down compounds such as trimethylamine oxide, peptides and amino acids into volatile species [33]. In general, the highest acceptable level of TVN in fish and shrimp meats has been suggested $25-30 \mathrm{mgN} / 100 \mathrm{~g}$ sample [34]. In this study, the variation of TVN in samples showed that TVN values during storage was under $20 \mathrm{mgN} / 100 \mathrm{~g}$ sample. So that, after six months storage, the TVN of dried shrimp in the cabinet-type air dryer was $14.0 \pm 5.66$ and the TVN of frozen shrimp in $-20^{\circ} \mathrm{C}$ was $9.00 \pm 1.41 \mathrm{mgN} / 100 \mathrm{~g}$ sample. Another researcher has reported that the TVN of dried shrimp at different packages (Styrofoam box, polythene bags and under bulk) during the sixth week were respectively $27 \pm 0.34$, $16.8 \pm 0.9$ and $21 \pm 0.98 \mathrm{mgN} / 100 \mathrm{~g}$ sample [35]. Therefore these results indicated that produced products were still in a good condition. Overall, the quality changes of frozen samples were better than dried samples.

FFA is used as a quality index for aquatic organisms and other food products. It can be changed with storage temperature, muscle type, species and fat content [28]. In this study, there was a quality difference between frozen and dried samples. The amount of FFA increased with increasing time, but no significant difference was observed in each sample. High levels of FFA during maintenance can result in increased oxidation and reduced quality. In another study by Sampaio et al. on fatty acids and cholesterol oxidation in salted and dried shrimp, they reported that the presence of high values of fatty acids and TBA in their samples indicated the degree of oxidation in the product, which was probably due to inadequate conditions of processing and storage [28]. But in this study, the storage conditions were quite controlled by preventing temperature fluctuations.

Typically, the first qualitative feature of food that is considered by the consumer is its appearance and color. Therefore, color is one of the most important and apparent aspects of food, which affects consumers' acceptance. Abnormal colors especially those caused by the growth of bacteria or the loss of food quality, not accepted by consumers. Hence, food manufacturers use colorpsychological effects to boost their sales. On the other hand, many of the reactions that occur during the heating and freezing processes in food can affect their color. The term of color parameters is usually used to check the changes of food substance during the treatment. These parameters include lightness or $L^{\star}$ from black (0) to white (100) color, redness or ${ }^{\star}$ from green (negative values) to red (positive values) color and yellowness or $b^{\star}$ from blue (negative values) to yellow (positive values) color [36]. Changes in $\mathrm{L}^{*}, \mathrm{a}^{\star}$, and $\mathrm{b}^{*}$ values during drying and freezing that occur due to the decomposition of pigments in food samples can increase the amount of total color change, getting brown and eventually quality loss of the products. In this study, the lightness of dried samples and frozen samples increased during storage and the redness and yellowness of dried shrimp by the cabinet-type air dryer were high due to the release of pigments from protein networks after drying. In general, the effect of time on $L^{*}$ parameters was statistically nonsignificant and on $\mathrm{a}^{\star}$ and $\mathrm{b}^{\star}$ parameters was significant in dried samples. In frozen samples, $\mathrm{b}^{\star}$ parameter was significant in sixth month. Niamnuy et al. studies on changes in the color of dry shrimp during storage for 16 weeks at different temperatures $\left(4,15\right.$ and $\left.25^{\circ} \mathrm{C}\right)$ reported that there is an association between astaxanthin degradation and shrimp color variations. So keeping the dried shrimp in a vacuum package with metallized films at the low temperature will keep the pigment in them [37]. Akonor et al. with the study on the physical properties of dried shrimps by conventional methods (oven and solar dryer) observed that the amount of lightness and yellowness at $55^{\circ} \mathrm{C}$ decreased and the redness increased [21].

One of the pleasures of life is to eat delicious food, which is not far from the reality. A delicious meal can destroy the fatigue of a hard day, and sometimes it is very pleasant. In this regard, sensory evaluation is a scientific method in which the properties of food are reflected in a way that can be observed and measured. In this study, the final acceptance of frozen and dried shrimp meat in the first and second months was excellent and good but in the sixth month, the frozen samples with the score of 4 and the dried samples with the score of 3 introduced. Therefore, the results demonstrate the quality of shrimp keeping in both methods of packaging in metallized films. Niamnuy et al. with the sensory evaluation of Penaeus indicus dried shrimp, reported that using salt at $2 \%$ concentration and at $120^{\circ} \mathrm{C}$ for 7 minutes received the best score for final acceptance by trained panel members [13]. 
The increase in the total bacteria of dried samples can be due to a gradual increase in the samples humidity with the increase in the shelf-life. Jayasinghe et al., with the study on the quality and shelf life of dry shrimp Penaeus indicus, reported that the number of microorganisms in peeled dried shrimp and packed in polyethylene bags, Styrofoam and bulk packages were respectively about $1.66 \times 105,5.88 \times 104$ and $3.33 \times 105$ were higher than the values observed in this study [35]. Another study by Niamnuy et al. found that with increasing boiling time and using more salt concentrations, the total number of microorganisms in the final product would be reduced [13]. In general, the results indicated that the drying and freezing process has significant influences on quality indices of shrimp meat. On the other hand, there were no many negative influences of drying and freezing processes on the fatty acid composition of shrimp meat.

\section{Conclusion}

Therefore, it can be resulted that both drying and freezing processes along with a suitable initial preparation and packaging prevent the lipid oxidation of shrimp meat during storage. The frozen samples showed lower TBA, PV, TVN, FFA and microorganism counts than the cabinet-type air-dried samples. But their values in both processes were in acceptable limits. Also, the result of sensory analyses showed that all samples have gained a good grade by trained panel members. Overall, this research provides basic quality information on non-native shrimp of Anzali lagoon, both frozen and dried for the first time in the total world for researchers. The present study also provides a possible application of small-sized shrimp as snacks in the future.

\section{Acknowledgment}

The research team would like to thank from Fereshteh Khodabandeh, Masoomeh Rahnama, Mojtaba Zareii and Azamat Dada Ghandi for their cooperation in different parts of this project. The support provided by Inland Waters Aquaculture Research Center, Iranian Fisheries Science Research Institute, Agricultural Research, Education and Extension Organization (Bandar Anzali, Iran) is truly acknowledged.

\section{References}

1. Harris M, Shiptsova R (2007) Consumer demand for convenience foods: demographics and expenditures. Food Distribution Res 38: 22-36.

2. De Grave S (2013) Macrobrachium nipponense. The IUCN red list of threatened species 2013: e.T197726A2497653.

3. Salman SD, Page TJ, Naser MD, Yasser AG (2006) The invasion of Macrobrachium nipponense (De Haan, 1849) (Caridea: Palaemonidae) into the Southern Iraqi Marshes. Aquatic Invasions 1: 109-15.

4. Cai Y, Ng PKL (2002) The freshwater palaemonid prawns (Crustacea: Decapoda: Caridea) of Myanmar. Hydrobiologia 487: 59-83.

5. De Grave S, Ghane A (2006) The establishment of the Oriental River Prawn, Macrobrachium nipponense (de Haan, 1849) in Anzali Lagoon, Iran. Aquatic Invasions 1: 204-8.

6. Bandani Gh, Khoshbavar Rostami H, Keymaram F, Sadighi O, Mirshekar D (2013) The first report of shrimp Mcrobrachium nipponense Alagol, Almagol and Ajigol Lagoons Golestan Province. Iran J Fish Sci 22: 164-70.

7. Larsen R, Eilertsen KE, Elvevoll EO (2011) Health benefits of marine foods and ingredients. Biotechnol Ad 29: 508-18.

8. Azizpour M, Mohebbi M, Khodaparast MHH (2016) Effects of foam-mat drying temperature on physicochemical and microstructural properties of shrimp powder. Innov Food Sci Emerg Technol 34: 122-6.

9. Chen XD, Mujumdar AS (2008) Drying Technologies in Food Processing. United Kingdom: Blackwell Publishing Ltd.

10. Razavi Shirzi H (2007) Seafood technology, principles of handling and processing. Pars Negar Press, Tehran

11. AOAC (2005) Official methods of analysis. Washington, DC, USA, 6500P.

12. USDA. United States Dept. of Agriculture.

13. Niamnuy C, Devahastin S, Soponronnarit S (2007) Quality changes of shrimp during boiling in salt solution. J Food Science 72: 289-97.

14. Parvaneh V (1998) Quality control and the chemical analysis. University of Tehran Press, Tehran.

15. Castro FAFD, Sant'Ana HMP, Campos FM, Costa NMB, Silva MTC, et al. (2007) Fatty acid composition of three freshwater fishes under different storage and cooking processes. Food Chem 103: 1080-90.

16. Tarladgis BG, Watts BM, Younathan MT (1960) A distillation method for the quantitative determination of malondialdehyde in rancid foods. Am Oil Chemist Soci 37: 44-8.

17. Woyewoda AD, Shaw SJ, Ke PJ, Burns BG (1986) Recommended laboratory methods for assessment of fish quality. Nova Scotia, Halifax.

18. Meilgaard MC, Civille GV, Carr BT (2007) Sensory evaluation techniques ( $4^{\text {th }}$ Edn.) CRC Press, Taylor and Francis Group, USA.

19. ISIRI (2007) Microbiology of food and animal feeding stuffs-Guideline of general requirements for examination. ISIRI 9899.

20. Wu T, Mao L (2008) Influences of hot air drying and microwave drying on nutritional and odorous properties of grass carp (Ctenopharyngodon idellus) fillets. Food Chem 110: 647-53.

21. Akonor PT, Ofori H, Dziedzoave NT, Kortei NK (2016) Drying Characteristics and Physical and Nutritional Properties of Shrimp Meat as Affected by Different Traditional Drying Techniques. Int J Food Sci 1: 1-5.

22. Gokoglu N, Yerlikaya P, Cengiz E (2004) Effects of cooking methods on the proximate composition and mineral contents of rainbow trout (Oncorhynchus mykiss). Food Chem 8: 19-22.

23. Shahidi F, Miraliakbari H (2004) Omega-3 fatty acids in health and disease. Part 1: Cardiovascular disease and cancer. Medical Food 7: 387-401.

24. Wong KW (2005) Clinical efficacy of n-3 fatty acid supplementation in patients with asthma. J Am Diet Assoc 105: 98-105.

25. Gomes HA, Silva EN, Nascimento MRL, Fukuma HT (2003) Evaluation of the 2- thiobarbituric acid method for the measurement of lipid oxidation in mechanically deboned gamma irradiated chicken meat. Food Chem 80: 433-7. 
26. Greene BE, Cumuze TH (1982) Relationship between TBA numbers and inexperienced panelists assessments of oxidized flavor in cooked beef. Food Sci 47: $52-4$.

27. Kraemer FB (2000) Analegis micologica and physical-chemical determination of salted-dry camamos marketed in the state of Rio de Janeiro. Dissertation submitted to the Federal Fluminense University, Brazil.

28. Sampaio GR, Bastos DHM, Soares RAM, Queiroz YS, Torres EAFS (2006) Fatty acids and cholesterol oxidation in salted and dried shrimp. Food Chem 95: 344-51.

29. Kong F, Singh RP (2011) Advances in instrumental methods to determine food quality deterioration. Food Beverage Stability Shelf Life $381-404$.

30. Rezaei M, Hosseini SF (2008) Quality Assessment of Farmed Rainbow Trout (Oncorhynchus mykiss) during Chilled Storage. J Food Sci 73: 93-6.

31. Fan W, Sun J, Chen Y, Qiu J, Zhang Y, et al. (2009) Effect of chitosan coating on quality and shelf life of silver carp during frozen storage. Food Chem 115: 66-70.

32. Kilinc B, Cakli S (2005) Determination of the shelf life of sardine (Sardina pilchardus) marinades in tomato sauce stored at $4{ }^{\circ} \mathrm{C}$. Food Control 16 : $639-44$.

33. Lopez-Caballero ME, G'omez-Guill'en MC, P'erez-Mateos M, Montero P (2004) A chitosan-gelatin blend as a coating for fish patties. Food Hydrocolloids 19: 303-11.

34. Gimenez B, Roncales P, Beltran JA (2002) Modified atmosphere packaging of filleted rainbow trout. Sci Food Agriculture 82: 1154-9.

35. Jayasinghe PS, Jayasinghe JMPK, Galappaththi CP (2006) Influence of different processing methods on quality and shelf life of dried shrimp. Sri Lanka J Aquatic Sci 11: 85-91.

36. Prachayawarakorn S, Soponronnarit S, Wetchacama S, Jaisut D (2002) Desorption isotherms and drying characteristics of shrimp in superheated steam and hot air. Drying Technol 20: 669-84.

37. Niamnuy C, Devahastin S, Soponronnarit S, Vijaya Raghavan GS (2008) Kinetics of astaxanthin degradation and color changes of dried shrimp during storage. J Food Eng 87: 591-600. 